OPEN ACCESS

ISSN 2579-5813 (online)

Edited by:

Moch. Bahak Udin By Arifin

Reviewed by:

Mohammad Faizal Amir

${ }^{*}$ Correspondence:

Amka Amka

Amka.plb@ulm.ac.id

Received: 8 Agustus 2020 Accepted: 9 September 2020 Published: 30 September 2020

Citation:

Amka A and Mirnawati M (2020) The Attitude of Islamic Religious Education Teachers Against The

Implementation of Inclusive Education at The Elementary School

Madrosatuna: Journal of Islamic

Elementary School. 4:2. 4:2. doi: 10.21070/madrosatuna.v4i2.79

\section{The Attitude of Islamic Religious Education Teachers Against The Implementation of Inclusive Education at The Elementary School Level}

\section{Sikap Guru Pendidikan Agama Islam Terhadap Penyelenggaraan Pendidikan Inklusif di Jenjang Sekolah Dasar}

\author{
Amka Amka*, Mirnawati Mirnawati \\ Universitas Lambung Mangkurat, Indonesia
}

This study aims to determine the attitude of Islamic Religious Education teachers in elementary schools towards the implementation of inclusive education. The study used a non-experimental quantitative approach with a survey method. Subjects or informants in this study were Islamic Religious Education teachers spread across 16 elementary schools in South Kalimantan. Data were analyzed using descriptive statistics using percentages; teacher attitudes were assessed based on five criteria, namely very good, good, sufficient, lacking, and very poor. These criteria adjust to the percentage range obtained. The results showed that the percentage of Islamic education teachers' attitudes towards implementing inclusive education in South Kalimantan was $67.18 \%$, which was categorized as quite good. Several variables affect teacher attitudes in terms of gender, recent education, experience in training.

Keywords: Attitude, Teacher, Islamic Education, Inclusive Education

Penelitian ini bertujuan untuk mengetahui sikap guru endidikan Agama Islam (PAI) di ekolah Dasar terhadap implementasi pendidikan inklusif. Penelitian menggunakan pedekatan kuantitatif non ekperimen dengan metode survey, subjek atau informan dalam penelitian ini adalah guru-guru mata pelajaran PAl yang tersebar dari 16 sekolah Dasar di Kalimantan Selatan. Data dianalisis menggunakan statistik deskriptif dengan menggunakan persentase, sikap guru dinilai berdasarkan 5 kriteria yaitu sangat baik, baik, cukup, kurang, dan sangat kurang. Kriteria tersebut menyesuaikan dengan rentang persentase yang diperoleh. Hasil penelitian menunjukkan bahwa presentase sikap guru PAI terhadap implementasi pendidikan inklusif di Kalimantan Selatan adalah 67,18\% termasuk dalam kriteria cukup baik. Beberapa variabel yang mempengaruhi sikap guru ditinjau dari jenis kelamin, pendidikan terakhir, pengalaman mengikuti pelatihan. 


\section{PENDAHULUAN}

Pendidikan inklusif sudah menjadi trend global, dalam prakteknya mendidik semua siswa, termasuk yang mengalami hambatan yang parah ataupun majemuk, di sekolah-sekolah reguler yang biasanya dimasuki anak-anak non berkebutuhan khusus Elisa and Wrastari (2013). Pendidikan inklusi merupakan praktek yang bertujuan untuk pemenuhan hak azasi manusia atas pendidikan, tanpa adanya diskriminasi, dengan memberi kesempatan pendidikan yang berkualitas kepada semua anak tanpa perkecualian, sehingga semua anak memiliki kesempatan yang sama untuk secara aktif mengembangkan potensi pribadinya dalam lingkungan yang sama Ainscow and Miles (2009).

Praktik seperti ini telah dilakukan oleh berbagai negara lebih dari 20 tahun semenjak Salamanca Statement dikeluarkan pada tahun 1994. Sebagai sebuah landasan filosofis dalam menyediakan akses yang setara bagi semua peserta didik, pendidikan inklusif mengubah lingkungan sekolah yang terbatas menjadi sebuah lingkungan yang lebih ramah dan dapat diakses oleh peserta didik yang beragam. Pemberian pendidikan yang bermutu bagi anak berkebutuhan khusus tentunya merupakan tantangan bagi pengelola sekolah, terutama untuk guru.

Pemberian pendidikan yang bermutu bagi anak berkebutuhan khusus tentunya merupakan tantangan, misalnya kebijakan yang tidak tepat Forbes (2007), kurangnya dukungan Hwang and Evans (2011), pelatihan yang kurang memadai Rajovic and Jovanovic (2013), serta sikap guru Unianu (2012). Adanya pendidikan inklusi menyebabkan tantangan baru pada guru, yaitu dalam hal melakukan perubahan yang signifkan terhadap program pendidikan dan mempersiapkan guru-guru untuk menghadapi semua kebutuhan siswa baik siswa berkebutuhan khusus maupun non berkebutuhan khusus Taylor and Ringlaben (2012).

Perubahan-perubahan yang diharapkan dalam pendidikan inklusif itulah yang menyebabkan perubahan sikap yaitu perbedaan sikap guru dalam menerima sistem penyelenggaraan pendidikan inklusif. Keberhasilan implementasi pendidikan inklusif terutama tergantung pada sikap dan kepedulian guru terhadap kebijakan inklusi. Sikap guru juga dipengaruhi oleh banyak variabel dan faktor terkait seperti jenis disabilitas, tingkat keparahan dan sifat kecacatan pada anak, pelatihan guru dan ketersediaan sumber daya. Persepsi guru tentang pengembangan pendidikan inklusif harus diingat karena ada kemungkinan bahwa persepsi mereka dapat mengubah perilaku dan penerimaan mereka terhadap siswa dengan disabilitas. Persepsi guru sangat berpengaruh dalam efektivitas penyelenggaraan pendidikan inklusif karena mereka memegang peran yang sangat penting dan bertanggung jawab atas implementasi layanan pendidikan inklusif Ehsaan et al. (2018) . Jika seorang guru tidak menginginkan anak tertentu di kelasnya, maka sangat sulit untuk melihat potensi yang dimiliki oleh seorang anak, guru tidak ada upaya memberikan pembelajaran yang dapat meminimalisir berbagai hambatan dari anak berkebutuhan khusus Saloviita (2020).

Pemahaman sikap guru terhadap inklusi sangat penting untuk perencanaan program di masa depan, baik guru kelas, guru pendamping khusus, maupun guru mata pelajaran Mahat (2008). Sehingga, penelitian ini bertujuan untuk melakukan pengkajian tentang sikap guru mata pelajaran PAI terhadap penyelenggaraan pendidikan inklusif. Bagi guru PAI, praktek inklusif bukanlah hal baru, mengingat dalam Agama Islam itu sendiri telah diajarkan prinsif-prinsif inklusif untuk bisa menerima dan menghargai setiap perbedaan, sebagaimana Firman Allah pada surah 'Abasa ayat 1-16 yang menjelaskan tentang seorang buta bernama Abdullah bin Ummi Maktum. Dia datang kepada Rasulullah S.A.W. meminta ajaran-ajaran tentang Islam; lalu Rasulullah S.A.W bermuka masam dan berpaling daripadanya, karena beliau sedang menghadapi pembesar Quraisy dengan pengharapan agar pembesar-pembesar tersebut mau masuk Islam. Maka turunlah surat ini sebagai teguran kepada Rasulullah S.A.W. Bahwa setiap orang tanpa terkecuali harus mendapatkan layanan pendidikan. Tidak memandang usia, mulai dari usia kandungan sampai dengan liang lahat, puntidak memandang fisik baik yang normal maupun yang mengalami hambatan. Dengan demikian, perjalanan menuntut ilmu dianggap sakral, tak kenal lelah, dan dilakukan untuk melengkapi dan menyelesaikan pendidikan seseorang.

Secara kelembagaan Kementerian Agama di Indonesia bertanggung jawab atas penyelenggaraan pendidikan keagamaan di sekolah dan memiliki komitmen guna memastikan bahwa layanan pendidikannya dapat dirasakan oleh semua anak tanpa kecuali. Guru agama dituntut memiliki visi, misi, dan wawasan yang luas serta kemampuan profesional yang memadai dalam perencanaan, pengorganisasian, pelaksanaan dan pengawasan penyelenggaraan pendidikan. Beberapa tugas guru PAI kaitannya dengan penyelengaran pendidikan inklusif di sekolah, diantaranya sebagai berikut: (1) Mengelola pembelajaran yang berpusat pada peserta didik dalam kelas yang beragam; (2) Menciptakan lingkungan kelas yang inklusif; (3) Menangani kebutuhan pembelajaran peserta didik secara akomodatif; (4) Merencanakan, melaksanakan, dan menilai program pembelajaran sejalan dengan landasan pendidikan yang berasaskan demokrasi, berkeadilan, dan tanpa diskriminasi (Dirjen Pendidikan Islam, 2017).

Dengan demikian, dirasa sangat perlu melakukan penelitian terkait sikap guru PAI terhadap penyelenggaraan pendidikan inklusif, apakah sikap yang di tunjukkan oleh guru PAI telah sesuai dengan ajaran Agama Islam dan amanat kebijakan Kementerian Agama Republik Indonesia.

\section{METODE}

Penelitian ini menggunakan pendekatan kuantitatif non eksperimen dengan metode survey. Penelitian survey digunakan untuk mengumpulkan informasi berbentuk opini terhadap isu-isu tertentu, informasi yang dikumpulkan untuk mendeskripsikan beberapa karakteristik tertentu seperti, 
kemampuan, sikap, kepercayaan dan pengetahuan Sukmadinata (2010). Dalam penelitian survey ini berfokus dalam mendeskripsikan sikap guru PAI terhadap penyelenggaraan pendidikan inklusif di sekolah dasar. Subjek dalam penelitian ini adalah guru-guru mata pelajaran PAI di jenjang sekolah dasar dari 16 sekolah dasar penyelenggara pendidikan inklusi di Kalimantan Selatan.

Pengumpulan data dilakukan melalui kuesioner. Dalam pelaksanaannya, peneliti melakukan penyebaran angket ke setiap sekolah dengan menggunakan google form. Data yang terkumpul kemudian dianalisis menggunakan statistik deskripitif dengan ketentuan sebagai berikut:

persentase sikap guru PAI $=\frac{(\text { skor perolehan })}{(\text { skor maksimal })} \times 100$

Persentase yang diperoleh kemudian dimaknai sesuai dengan panduan dibawah ini:

\section{HASIL DAN PEMBAHASAN}

Tujuan dari penelitian ini adalah untuk mengetahui sikap guru PAI di ekolah Dasar terhadap implementasi pendidikan inklusif. Sikap guru diukur menggunakan survei dengan lima kriteria yaitu sangat baik; baik; cukup; kurang; dan sangat kurang. Sikap guru PAI terhadap implementasi pendidikan inklusif disajikan pada Tabel 3 berikut:

Hasil penelitian menunjukkan bahwa sikap guru Pendidikan Agama Islam (PAI) terhadap implementasi pendidikan inklusif di Kalimantan Selatan 67,18\% dengan kriteria sikap cukup baik. Temuan dalam penelitian ini menunjukkan beberapa sikap guru PAI dalam menyikapi implementasi pendidikan inklusif, diantaranya sebagai berikut: (1) memiliki kekhawatiran yang berlebihan terkait penolakan terhadap anak berkebutuhan khusus; (2) memiliki perasaan takut mereka tidak dapat berinterkasi dengan siswa berkebutuhan khusus; (3) kesulitan membuat kontak atau berkomunikasi dengan siswa berkebutuhan khusus; (4) khawatir akan beban kerja yang semakin banyak jika mengahadapi atau mengajar siswa berkebutuhan khusus di kelas mereka; (5) beberapa diantara mereka beranggapan bahwa merupakan hal yang mengerikan jika berhadapan dengan siswa berebutuhan khusus; (6) beberapa diantara mereka juga beranggapan bahwa mereka akan menjadi lebih stress jika berhadapan dengan siswa berkebutuhan khusu di kelas; (7) perasaan khawatir bahwa mereka tidak memiliki pengetahuan dan keterampilan yang dibutuhkan untuk mengajar siswa berkebutuhan khusus; (8) disisi lain, sebagian besar guru menyatakan bahwa siswa berkebutuhan khusus harus diberikan kesempatan untuk berpartisipasi dalam kelas umum, jika memungkinkan. Sikap negatif terhadap inklusi dapat dikaitkan dengan lingkungan belajar di kelas yang kurang inklusif, sikap guru yang kurang positif terhadap inklusi. Monsen et al. (2014)

Penelitian ini berfokus pada pernyataan setuju atau tidak setuju subjek penelitian terhadap item pernyataan tertentu, dan hasilnya menunjukkan bahwa sebagian besar guru sepakat bahwa siswa berkebutuhan khusus berhak dan harus diberi kesempatan untuk terlibat aktif dalam kegiatan pembelajaran di kelas reguler. Namun, walaupun demikian sejumlah besar guru juga tampak menunjukkan beberapa sikap yang tidak mendukung pemberian layanan siswa berkebutuhan khusus di kelas reguler, dengan menunjukkan ketidakmampuan berkomunikasi dengan siswa berkebutuhan khusus, merasa stres dan beranggapan bahwa beban kerjanya akan semakin berat jika menghadapi siswa berkebutuhan khusus di kelas mereka. Hasil ini dapat diartikan bahwa mereka mendukung pendidikan inklusif bagi siswa berkebutuhan khusus dalam teori, tetapi menyatakan keberatan dalam implementasinya di lapangan Koutrouba et al. (2008); Memisevic and Hodzic (2011); Haq and Mundia (2012); Khochen and Radford (2012).

Mengenai veriabel yang mempengaruhi sikap guru, tidak ditemukan perbedaan sikap yang signifikan antara laki-laki dan perempuan. Temuan ini sejalan dengan beberapa penelitian yang tidak menemukan perbedaan sikap antara guru laki-laki dan guru perempuan de Boer et al. (2012); Jerlinder et al. (2010); Memisevic and Hodzic (2011); Galaterou and Antoniou (2017) . Namun juga terdapat penelitian yang menemukan bahwa guru perempuan memiliki kepedulian dan empati yang lebih baik pada anak berkebutuhan khusus sehingga menunjukkan sikap yang lebih positif terhadap penyelenggaraan pendidikan inklusif daripada guru lakilaki Alquraini (2012). Guru dalam pandangan Islam adalah seorang pribadi yang mempunyai kecakapan ilmu dan profesional dalam menjalankan proses pembelajaran. Guru yang mengembangkan nilai-nilai Islam inklusif adalah guru yang membebaskan dan memerdekakan. Guru yang memposisikan subjek didik sebagai manusia merdeka dan memiliki potensi hingga pembelajaran memberi ruang yang seluas-luasnya bagi subjek didik untuk berkembang secara maksimal Kurnialoh (2011).

Latar belakang pendidikan juga tidak menunjukkan pengaruh yang signifikan terhadap sikap guru, guru PAI dalam penelitian ini memiliki latar belakang pendidikan sarjana endidikan Agama Islam. Pendidikan Islam mendapat ujian dalam membangun individu di satu sisi memiliki komitmen yang kuat terhadap agama yang dianut, di sisi lain tumbuhnya sikap positif dan toleransi terhadap respon atas keragaman golongan di dalam internal umat Islam.

Dengan menumbuhkan sikap positif dan toleransi antar golongan diharapkan dapat mewujudkan kerukunan yang menjadi semboyan kebanggaan bangsa Indonesia yaitu bhineka tunggal ika, Islam mempunyai watak inklusif yang sifatnya terbuka, begitu pun seharusnya pendidikan Islam. Menurut Sayyid Quttub bahwa sudah seharusnya Islam memberikan suasana partisipasi sosial, perlakuan yang baik dan pergaulan kepada mereka yang berbeda pandangan terhadap kita (Lajnah, 2014) dalam Daimah (2018) . Dalam Al-Qur'an sebenarnya gagasan tentang pendidikan Inklusif termaktub dalam beberapa ayat. Diantara salah satunya adalah Qs. AlHujurat/49 : 10 - 13. Dalam surah tersebut memaparkan tentang etika atau akhlak dalam berhubungan antar sesama manusia. Sebagaimana dijelaskan dalam Al Qur'an Surah al-Hujurat 
TABLE 1 | Daftar Nama Sekolah Sampel Penelitian

\begin{tabular}{ll}
\hline No & Nama Sekolah \\
1 & SDN Mantimin 2 \\
2 & SDN Basirih 11 \\
3 & SDN SN Sungai Mia 5 \\
4 & SDN Mandurian \\
5 & SDN Tangkawang \\
6 & SDN Rantau Kiwa 1 \\
7 & SDN1 Loktabat utara \\
8 & SDN 5 Syamsudin Noor \\
9 & SDN Tabudarat Hulu \\
10 & SDN 1 Banua Kepayang \\
11 & SDN Tambarangan 1 \\
12 & SDN 2 Sungai Nyamuk \\
13 & SDN Telaga Langsat \\
14 & SDN Kepayang \\
15 & SDN Durian Gantang \\
16 & SDN 2 Pantai Hambawang Timur \\
\hline
\end{tabular}

TABLE 2 | Kriteria persentase sikap guru PAI

\begin{tabular}{ll}
\hline Persentase & Kriteria sikap guru PAI \\
$91 \%-100 \%$ & Sangat baik \\
$76 \%-90 \%$ & Baik \\
$61 \%-75 \%$ & Cukup \\
$51 \%-60 \%$ & Kurang \\
$\leq 50 \%$ & Sangat kurang \\
\hline
\end{tabular}

TABLE 3 | Sikap Guru Pendidikan Agama Islam Terhadaplmplementasi Pendidikan Inklusif

\begin{tabular}{|c|c|c|c|c|c|c|}
\hline No & Nama (Inisial) & Jenis Kelamin & Usia & Pend. Terakhir & $\begin{array}{l}\text { Menfedikstintase Sikap } \\
\text { Pelati- } \\
\text { han }\end{array}$ & $\begin{array}{l}\text { Ket. } \\
\text { Sikap }\end{array}$ \\
\hline 1 & ABD & $\mathrm{L}$ & 40 & S1 PAl & Tidak7,18 & Cukup \\
\hline 2 & ALW & $L$ & 32 & S1 & TidaK0,31 & Cukup \\
\hline 3 & & $\mathrm{~L}$ & 56 & S1 & Tidak8,75 & Cukup \\
\hline 4 & $P Z$ & $\mathrm{~L}$ & 40 & S1 & Ya 75 & Cukup \\
\hline 5 & SA & $L$ & 33 & $\mathrm{~S} 2$ & Tidak8,12 & Baik \\
\hline 6 & AMR & $\mathrm{L}$ & 41 & S1 & Ya 62,5 & Cukup \\
\hline 7 & YD & $\mathrm{L}$ & 53 & $\mathrm{~S} 1$ & Tidak4,06 & Cukup \\
\hline 8 & YND & $\mathrm{L}$ & 32 & S1 PAl & Ya 65,62 & Cukup \\
\hline 9 & SMD & $\mathrm{L}$ & 56 & S1 & TidafB7,18 & Cukup \\
\hline 10 & SHR & $\mathrm{L}$ & 52 & S1 & Tidat66,25 & Kurang \\
\hline 11 & $\mathrm{NHS}$ & & 44 & S1 & Tidak8,75 & Cukup \\
\hline 12 & ILW & & 31 & S1 & TidaßB2,5 & Cukup \\
\hline 13 & WUQ & & 51 & S1 PAl & Tidaßk5,62 & Cukup \\
\hline 14 & $\mathrm{RR}$ & & 21 & SLTA & Tidak8,75 & Cukup \\
\hline 15 & $\mathrm{R}$ & & 33 & S1 Tarbiyah & TidaK3,43 & Cukup \\
\hline 16 & $J A$ & & 59 & S1 & TidaßBO,93 & Kurang \\
\hline \multicolumn{3}{|c|}{ Rata-Rata } & & 67,18 & Cukup & \\
\hline
\end{tabular}

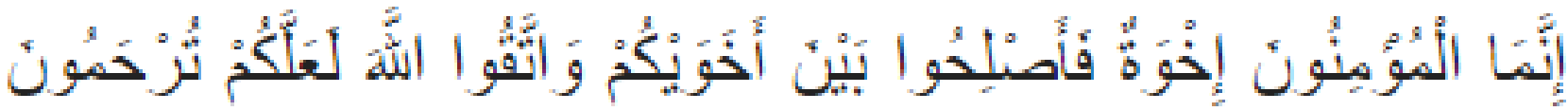

FIGURE 1 | Al Qur'an Surah al-Hujurat ayat 10 
ayat 10 bahwa setiap mukmin adalah bersaudara. Berikut pemaparannya.

Artinya: Sesungguhnya orang-orang mukmin adalah bersaudara, maka itu damaikanlah kedua saudaramu itu dan bertakwalah kepada Allah supaya kamu mendapat rahmat.

Maka sudah selayaknya internalisasi semangat dan nilainilai inklusif harus bersemayam dalam implementasi pendidikan Islam Habibi (2017). Tujuan pendidikan Islam harus dirumuskan dengan landasan dan semangat merawat perbedaan. Reorientasi pendidikan Islam yang berwawasan inklusif dengan memadukan aspek kesalehan individu dan kesalehan sosial sebagai upaya mengembangkan kerukunan umat serta upaya peningkatan kualitas pendidikan perlu untuk diperhatikan. Pendidikan yang dimaksud adalah pendidikan yang melahirkan akhlak karimah dengan indikator adanya sikap jujur, tenggang rasa, dan cinta kasih antar sesamanya (Nazaruddin, 2007) dalam Habibi (2017).

Salah satu variabel yang juga mempengaruhi sikap guru PAI terhadap implementasi pendidikan inklusif adalah keikutsertaan dalam pelatihan pendidikan khusus, subjek pada penelitian ini sebagain besar tidak pernah mengikuti pelatihan tentang pendidikan khusus, tiga orang guru diataranya pernah mengaku pernah mengikuti pelatihan, namun materi pelatihan yang didapatkan belum sampai pada penanganan anak berkebutuhan khusus di kelas inklusi, dengan demikian, sikap yang ditunjukkan cenderung sama denganguru-guru yang tidak pernah mendapatkan pelatihan. Sikap positif guru dapat dipupuk baik melalui pelatihan tentang pendidikan khusus dan pengalaman konstruktif dengan siswa berkebutuhan khusus Praisner (2003); Subban and Sharma (2006). Kegiatan pelatihan merupakan waktu yang tepat untuk mengatasi masalah yang dihadapi guru PAI dalam menghadapi anak berkebutuhan khusus di kelas mereka, dan juga memungkinkan untuk mengubah sikap guru terhadap pengajaran siswa yang beragam serta terhadap siswa berkebutuhan khusus.

Salah satu variabel yang juga mempengaruhi sikap guru PAI terhadap implementasi pendidikan inklusif adalah keikutsertaan dalam pelatihan pendidikan khusus, subjek pada penelitian ini sebagain besar tidak pernah mengikuti pelatihan tentang pendidikan khusus, tiga orang guru diataranya mengaku pernah mengikuti pelatihan, namun materi pelatihan yang didapatkan belum sampai pada penanganan anak berkebutuhan khusus di kelas inklusi, dengan demikian, sikap yang ditunjukkan cenderung sama denganguru-guru yang tidak pernah mendapatkan pelatihan. Sikap positif guru dapat dipupuk baik melalui pelatihan tentang pendidikan khusus dan pengalaman konstruktif dengan siswa berkebutuhan khusus Praisner (2003); Subban and Sharma (2006). Kegiatan pelatihan merupakan waktu yang tepat untuk mengatasi masalah yang dihadapi guru PAI dalam menghadapi anak berkebutuhan khusus di kelas mereka, dan juga memungkinkan untuk mengubah sikap guru terhadap pengajaran siswa yang beragam serta terhadap siswa berkebutuhan khusus.
Pembentukan sikap positif guru sangat dimediasi oleh pendidikan yang memadai sehubungan dengan pendidikan inklusif bagi siswa berkebutuhan khusus, dukungan dari kolega dan manajemen sekolah. Persepsi guru tentang kompetensi mereka dalam memfasilitasi lingkungan pembelajaran bagi anak berkebutuhan khusus di kelas inklusif, dan perilaku yang ditunjukkan siswa berkebutuhan khusus turut mempengaruhi sikap guru Monsen et al. (2014). Para guru khawatir tentang kompetensi mereka untuk memasukkan siswa berkebutuhan khusus di kelas mereka, beberapa guru merasa kurang terlatih, dan menyatakan kesulitan dalam memantau siswa lain ketika terdapat siswa berkebutuhan khusus di kelas Forlin et al. (2011) . Dengan adanya peningkatan pengetahuan guru PAI melalui kegiatan pelatihan tentang pendidikan khusus, maka guru akan menjadi lebih percaya diri dalam menangani siswa berkebutuhan khusus di kelas mereka. Kepercayaan diri guru dianggap sebagai faktor penting yang memiliki dampak signifikan pada sikap mereka terhadap implementasi pendidikan inklusif. Guru yang percaya diri cenderung menunjukkan sikap yang lebih positif terhadap inklusi Subban and Sharma (2006). Semakin tinggi rasa percaya diri seoarang guru, maka guru akan menunjukkan sikap yang lebih positif terhadap inklusi dan tidak merasa terbebani dalam mengajar siswa berkebutuhan khusus Lifshitz et al. (2004). Guru yang memiliki kepercayaan diri yang rendah maka akan merasa kekhawatiran dan stres saat menghadapi siswa berkebutuhan khusus, sehingga tidak dapat mengakomodasi kebutuhan belajar siswa berkebutuhan khusus di kelas reguler Ewing et al. (2018).

Selain intervensi yang ditujukan untuk guru berupa pelatihan, juga perlu ada undang-undang yang lebih spesifik yang mencakup masalah pendidikan inklusi. Undang-undang atau kebijakan pemerintah terkait pendidikan inklusif dan sikap guru yang positif serta dengan dukungan profesional dapat menyukseskan penyelenggaraan pendidikan inklusif. Keterpaduan guru yang kompeten, sumber daya yang memadai dan dukungan sekolah disinyalir mampu mewujudkan implementasi pendidikan inklusif yang sesuai dengan harapan Mahdi and Bukamal (2019) .

\section{KESIMPULAN}

Berdasarkan paparan hasil penelitian dan pembahasan di atas, dapat disimpulkan bahwa sikap guru PAI terhadap implementasi pendidikan inklusif di Kalimantan Selatan termasuk dalam kriteria cukup baik atau cukup positif. Sebagian besar guru sepakat bahwa siswa berkebutuhan khusus berhak dan harus diberi kesempatan untuk terlibat aktif dalam kegiatan pembelajaran di kelas reguler. Namun, walaupun demikian sejumlah besar guru juga tampak menunjukkan beberapa sikap yang tidak mendukung pemberian layanan siswa berkebutuhan khusus di kelas reguler, dengan menunjukkan ketidakmampuan berkomunikasi dengan siswa berkebutuhan khusus, merasa stres dan beranggapan bahwa beban kerjanya akan 
semakin berat jika menghadapi siswa berkebutuhan khusus di kelas mereka. Kurangnya pengetahuan dan keerampilan guru PAI dalam pembelajaran siswa berkebutuhan khusus di kelas mereka, maka perlu adanya pengadaan pelatihan pendidikan khusus yang ditujukan kepada guru PAI secara

\section{REFERENCES}

Ainscow, M. and Miles, S. (2009). Developing Inclusive Education Systems: How Can We Move Policies Forward? International Bureau of Education, 1-9.

Alquraini, T. A. (2012). Factors related to teachers' attitudes towards the inclusive education of students with severe intellectual disabilities in Riyadh, Saudi. Journal of Research in Special Educational Needs 12, 170-182. doi: 10.1111/j.14713802.2012.01248.x.

Daimah (2018). Pendidikan Inklusif Perspektif QS. Jurnal Al-Thariqah 3, 54-65.

de Boer, A., Pijl, S. J., and Minnaert, A. (2012). Students' Attitudes towards Peers with Disabilities: A review of the literature. International Journal of Disability, Development and Education 59, 379-392. doi: 10.1080/1034912x.2012.723944.

Ehsaan, F., Khan, M. S. G., and Gulzar, S. (2018). Factors Influencing The Teacher's Attitude and Concerns Towards Inclusive Education of Special Need Children. AJAHS 3, 51-56.

Elisa, S. and Wrastari, A. T. (2013). Sikap Guru Terhadap Pendidikan Inklusi Ditinjau Dari Faktor Pembentuk Sikap. Jurnal Psikologi Perkembangan dan Pendidikan 2, 1-10.

Ewing, D. L., Monsen, J. J., and Kielblock, S. (2018). Teachers' attitudes towards inclusive education: a critical review of published questionnaires. Educational Psychology in Practice 34, 150-165. doi: 10.1080/02667363.2017.1417822.

Forbes, F. (2007). Towards inclusion: an Australian perspective. Support for Learning 22, 66-71. doi: https://doi.org/10.1111/j.1467-9604.2007.00449.x.

Forlin, C., Earle, C., Loreman, T., and Sharma, U. (2011). The Sentiments, Attitudes, and Concerns about Inclusive Education Revised (SACIE-R) Scale for Measuring Pre-Service Teachers' Perceptions about Inclusion. Exceptionality Education International 21, 50-65.

Galaterou, J. and Antoniou, A.-S. (2017). Teachers' Attitudes towards Inclusive Education: The Role of Job Stressors and Demographic Parameters. International Journal Of Special Education 32, 643-658.

Habibi, M. M. (2017). Corak Pendidikan Islam Inklusif. Jurnal eL-Tarbawi 10, 3548. doi: https://doi.org/10.20885/tarbawi.vol9.iss1.art3.

Haq, F. S. and Mundia, L. (2012). Comparison of Brunei Preservice Student Teachers' Attitudes to Inclusive Education and Specific Disabilities: Implications for Teacher Education. The Journal of Educational Research 105, 366-374. doi: 10.1080/00220671.2011.627399.

Hwang, Y.-S. and Evans, D. (2011). Attitudes towards inclusion: gaps between belief and practice. International Journal of Special Education 26, 136-146.

Jerlinder, K., Danermark, B., and Gill, P. (2010). Swedish primary-school teachers' attitudes to inclusion - the case of $\mathrm{PE}$ and pupils with physical disabilities. European Journal of Special Needs Education 25, 45-57. doi: 10.1080/ 08856250903450830.

Khochen, M. and Radford, J. (2012). Attitudes of teachers and headteachers towards inclusion in Lebanon. International Journal of Inclusive Education 16, 139-153. doi: 10.1080/13603111003671665.

Koutrouba, K., Vamvakari, M., and Theodoropoulos, H. (2008). SEN students' inclusion in Greece: factors influencing Greek teachers' stance. European Journal of Special Needs Education 23, 413-421. doi: 10.1080/08856250802387422.

Kurnialoh, N. (2011). Pendidikan Agama Islam Berwawasan Inklusif-Pluralis. INSANIA 18, 389-400. berkesinambungan, sehingga guru PAI akan lebih percaya diri dalam membelajarkan siswa berkebutuhan khusus, yang pada akhirnya diharapkan sikap guru terhadap implementasi pendidikan inklusif akan lebih baik atau lebih positif sesuai dengan ajaran Islam.

Lifshitz, H., Glaubman, R., and Issawi, R. (2004). Attitudes towards inclu sion: the case of Israeli and Palestinian regular and special education teachers. European Journal of Special Needs Education 19, 171-190. doi: 10.1080/ 08856250410001678478 .

Mahat, M. (2008). The Development of a Psychometrically-Sound Instrument to Measure Teachers' Multidimensional Attitudes toward Inclusive Education. INTERNATIONAL JOURNAL OF SPECIAL EDUCATION 23, 82-92.

Mahdi, O. A. and Bukamal, H. (2019). Pre-Service Teachers' Attitudes Toward Inclusive Education During Their Studies in Bahrain Teachers College. SAGE Open 9, 215824401986577-215824401986577. doi: 10.1177/ 2158244019865772.

Memisevic, H. and Hodzic, S. (2011). Teachers' attitudes towards inclusion of students with intellectual disability in Bosnia and Herzegovina. International Journal of Inclusive Education 15, 699-710. doi: 10.1080/13603110903184001.

Monsen, J. J., Ewing, D. L., and Kwoka, M. (2014). Teachers' attitudes towards inclusion, perceived adequacy of support and classroom learning environment. Learning Environments Research 17, 113-126. doi: 10.1007/s10984-013-9144-8.

Praisner, C. L. (2003). Attitudes of Elementary School Principals toward the Inclusion of Students with Disabilities. Exceptional Children 69, 135-145. doi: $10.1177 / 001440290306900201$.

Rajovic, V. and Jovanovic, O. (2013). The Barriers to Inclusive Education: Mapping 10 Years of Serbian Teachers' Arritudes Toward Inclusive Education. Journal of Special Education and Rehabilitation 14, 78-97. doi: 10.2478/jser-2013-001210. 2478.

Saloviita, T. (2020). Attitudes of Teachers Towards Inclusive Education in Finland. Scandinavian Journal of Educational Research 64, 270-282. doi: 10.1080/ 00313831.2018.1541819.

Subban, P. and Sharma, U. (2006). Primary school teachers' perceptions of inclusive education in Victoria. Australia. International Journal of Special Education 21, $42-52$.

Sukmadinata, N. S. (2010). Metode Penelitian Pendidikan (Bandung: PT. Remaja Rosdakarya), 1-326.

Taylor, R. W. and Ringlaben, R. P. (2012). Impacting Pre-service Teachers' Attitudes toward Inclusion . Higher Education Studies 2, 16-23. doi: http://dx.doi.org/10. 5539/hes.v2n3p16.

Unianu, E. M. (2012). Teachers' attitudes towards inclusive education. Procedia Social and Behavioral Sciences 33, 900-904. doi: 10.1016/j.sbspro.2012.01.252.

Conflict of Interest Statement: The authors declare that the research was conducted in the absence of any commercial or financial relationships that could be construed as a potential conflict of interest.

Copyright (c) 2020 Amka and Mirnawati. This is an open-access article distributed under the terms of the Creative Commons Attribution License (CC BY). The use, distribution or reproduction in other forums is permitted, provided the original author(s) and the copyright owner(s) are credited and that the original publication in this journal is cited, in accordance with accepted academic practice. No use, distribution or reproduction is permitted which does not comply with these terms. 